\title{
PHARMACOECONOMIC EVALUATION OF ANTIDIABETIC THERAPY AT A TERTIARY HEALTH CARE INSTITUTION
}

\author{
ANIRUDH M*, KARTHIKEYAN K \\ Department of Pharmacy Practice, SRM College of Pharmacy, SRM Institute of Science and Technology, Chennai, Tamil Nadu, India. Email: \\ anirudhmkn1997@gmail.com
}

Received: 31 March 2021, Revised and Accepted: 03 May 2021

\section{ABSTRACT}

Objective: The present study was aimed to estimate the direct cost of pharmacotherapy, laboratory tests, and medical tests incurred by patients, to analyze the health-related quality of life (HRQoL) for diabetic patient with macrovascular complications, to estimate the direct health system costs of treating patients with diabetes, to analyze the drug utilization trend of anti-diabetic therapy, to estimate the annual total direct medical costs of managing patients with diabetes, and to evaluate pharmacoeconomic impact on outcomes or beneficence of diabetic therapy.

Methods: A prospective cross-sectional study at SRM Medical College, Hospital and Research Centre, Kattankulathur - General Medicine Department with a sample size of 200 patients.

Results: During study, 200 diabetic patients were enrolled based on the inclusion and exclusion criteria at SRM Medical College and Hospital. Out of 200 diabetic patients (100\%), 83 (41.5\%) patients were females, and 117 (58.5\%) patients were males. Out of 200 (100\%) diabetic patients, 18 (9\%) of the patient were within the age group of 20-39 years, 78 (39\%) of the patients were within the age range of 40-59, the group with the highest frequency was aged from 60 to 79 with 93 (46.5\%) patients while the age group of 80-99 had the lowest frequency of 11 (5.5\%) of patients. The patient sample had 14 (7\%) type 1 diabetic patients out of which two patients (14.3\%) were females and 12 (85.7\%) were males. A total of $186(93 \%)$ patients had type 2 diabetes where 81 (43.5\%) were females and 105 (56.5\%) were males. Drug utilization trend: In the patient sample, anti-diabetic drugs were the most frequently used. Oral and parenteral dosage forms were used which included insulin administration subcutaneously and intravenously together with intravenous fluids to correct cases of hyperglycemia and hypoglycemia. HRQoL is the measure of patient value in terms of impact of disease and its treatment on physical functioning and psychological well-being. Out of 200 patients, $25 \%$ had severe problems with mobility.

Conclusion: Diabetes is characterized by a very high-cost burden. Education on the prevention and management of diabetes must be prioritized. It must be provided to the diabetic patients and the society at large. Therefore, it is suggested that health-care providers and policy-makers must put more attention to the factors that result in an increased hospital care. A lower financial burden on patients would greatly increase the treatment compliance, complications, and comorbidity progression. This will result in a reduction of diabetes economic burden on patients, society, and healthcare system. Further multicenter studies can be carried out in a larger population in different geographical regions in India or it can be done at a national scale.

Keywords: Diabetes, Health, Co-morbidity, Compliance.

(C) 2021 The Authors. Published by Innovare Academic Sciences Pvt Ltd. This is an open access article under the CC BY license (http://creativecommons.org/ licenses/by/4.0/) DOI: http://dx.doi.org/10.22159/ajpcr.2021v14i6.41653. Journal homepage: https://innovareacademics.in/journals/index.php/ajpcr

\section{INTRODUCTION}

The health-care system currently is evolving from the conventional systems due to the advancement in medical technology, for instant, diagnostic and therapeutic options thereby resulting in an increased financial burden on patients and the society at large [1]. Despite the improved quality of care provided in the health sector globally, advanced medical technology has significantly increased the operating cost and the daily medical expenditure [2]. Diabetes is usually treated for a lifetime; hence, it is characterized by high costs due to its chronicity, complications, and high resource utilization. Health outcomes research and patient-reported outcomes especially, aim at understanding patient value in terms of the impact of disease and its treatment on physical functioning and psychosocial well-being, known also as health-related quality of life (HRQoL). It is the description and analysis of the costs of drug therapy to health care systems and society [3]. In India, the situation has worsened claiming nearly 62 million Indian population with an average onset of 42.5 years and it is expected to rise to 109 million cases by 2035 [4]. Pharmacoeconomics is a subfield of health economics. The pharmacoeconomics field consists of comparing outcomes, whether clinical, humanistic, or economic and resource consumption or costs of pharmaceutical programs or services to the next best alternatives from the selected perspectives [5]. The main goal for this approach is to determine, measure value, and establish the link between both outcomes and resource consumption for the relative worth of selected services, programs, and pharmaceutical products can be determined. The combination of cost and outcome analysis is in different forms [Table 1].

\section{METHODS}

Study design

This was a prospective cross-sectional study.

\section{Study site}

This study was conducted at the SRM Medical College, Hospital and Research Centre, Kattankulathur - General Medicine Department.

\section{Sample size}

The sample size was $n=200$ patients.

Ethical committee approval

Ethics clearance number: 1278/IEC/2017.

\section{Inclusion criteria}

- Patients with either type 1 or type 2 diabetes mellitus on therapy

- Inpatients and outpatients

- Sex - male and female 
- $\quad$ Age - 20-90 years

- Patients willing to give informed consent.

\section{Exclusion criteria}

The following criteria were excluded from the study:

- Pregnant and lactating women

- Patient age $<20$ years

- Patients not willing to give informed consent.

The personnel costs for physicians, pharmacists, and nurses will be calculated. The average time for completion of 15 random observations for completion of tasks such as consultation, dispensing, and blood tests was determined and recorded. The salary of health professionals will be obtained from the accounts department of the hospital. The average will be considered when necessary and the mean salary per minute is calculated [Table 2]

\section{Equation 4}

Mean salary/min=Annual salary/Hours/week*no of weeks/annum*6

- In the calculation, the respective number of visits will be considered. Furthermore, the transport cost for each patient will be computed for

Table 1: Types of pharmacoeconomics evaluation techniques

\begin{tabular}{|c|c|c|c|}
\hline Method & $\begin{array}{l}\text { Cost } \\
\text { measurement }\end{array}$ & $\begin{array}{l}\text { Outcome } \\
\text { measurement }\end{array}$ & Decision rule \\
\hline $\begin{array}{l}\text { Cost- } \\
\text { minimization } \\
\text { analysis }\end{array}$ & Monetary & $\begin{array}{l}\text { Outcomes of } \\
\text { alternatives } \\
\text { assumed } \\
\text { identical }\end{array}$ & $\begin{array}{l}\text { Lowest } \\
\text { monetary cost }\end{array}$ \\
\hline $\begin{array}{l}\text { Cost- } \\
\text { effectiveness } \\
\text { analysis }\end{array}$ & Monetary & $\begin{array}{l}\text { All outcomes } \\
\text { translated into } \\
\text { monetary units }\end{array}$ & $\begin{array}{l}\text { Net monetary } \\
\text { gain }\end{array}$ \\
\hline $\begin{array}{l}\text { Cost utility } \\
\text { analysis }\end{array}$ & Monetary & $\begin{array}{l}\text { Non-monetary } \\
\text { physical units of } \\
\text { effectiveness }\end{array}$ & $\begin{array}{l}\text { CE ratios using } \\
\text { incremental } \\
\text { of marginal } \\
\text { analysis }\end{array}$ \\
\hline $\begin{array}{l}\text { Cost utility } \\
\text { analysis }\end{array}$ & Monetary & $\begin{array}{l}\text { Utility values } \\
\text { and quality } \\
\text { adjusted life } \\
\text { years (QALY) }\end{array}$ & $\begin{array}{l}\text { Cost per QALY } \\
\text { and league } \\
\text { tables }\end{array}$ \\
\hline $\begin{array}{l}\text { Cost outcomes } \\
\text { analysis or cost- } \\
\text { consequence } \\
\text { analysis }\end{array}$ & Monetary & $\begin{array}{l}\text { Combination } \\
\text { of quality of } \\
\text { life and natural } \\
\text { units }\end{array}$ & $\begin{array}{l}\text { Choice left to } \\
\text { the decision } \\
\text { maker }\end{array}$ \\
\hline
\end{tabular}

Table 2: Types of outcomes

\begin{tabular}{|c|c|c|}
\hline Clinical outcomes & $\begin{array}{l}\text { Humanistic } \\
\text { outcomes }\end{array}$ & Economic outcomes \\
\hline $\begin{array}{l}\text { Final Mortality e.g. } \\
\text { • Number of deaths/lives } \\
\text { saved } \\
\text { - Life years gained } \\
\text { • Cure rate } \\
\text { Morbidity, for example, stroke, } \\
\text { myocardial infarction, days } \\
\text { of hospitalization, days of } \\
\text { disability } \\
\text { Intermediate mortality, for } \\
\text { example, } \\
\text { • Cases identified } \\
\text { • Response rate } \\
\text { Morbidity, for example, BP, } \\
\text { serum cholesterol, drugs } \\
\text { correctly prescribed }\end{array}$ & $\begin{array}{c}\text { Intangibles } \\
\text { • Quality } \\
\text { of life } \\
\text { - Utility } \\
\text { (QALY) }\end{array}$ & $\begin{array}{l}\text { Utilization of health } \\
\text { resources e.g. } \\
\text { - Hospital days } \\
\text { - Physician visits } \\
\text { - Medication } \\
\text { - Services such as } \\
\text { nursing or food } \\
\text { - Delivery }\end{array}$ \\
\hline
\end{tabular}

all visits using the standard tariff and patient destination as indicated in the given residential address in the patient's address

- Drug costs are going to be obtained from the pharmacy department of the hospital and therefore the cost per defined daily dose is calculated considering the duration of therapy. Furthermore, the cost of diagnosis will be obtained from the hospital laboratory. All the above-mentioned costs will be added for each patient and for all patients to obtain the total. The average cost per patient was then calculated and recorded.

\section{RESULTS}

\section{Demographic variables}

The project entitled "pharmacoeconomic evaluation of anti-diabetic therapy at a tertiary health care institution" was conducted as described in the previous chapters for 6 months. During the study, 200 diabetic patients were enrolled based on the inclusion and exclusion criteria at SRM Medical College and Hospital. The data on patients were analyzed statistically and the outcomes are presented in this section.

\section{Gender distribution}

Out of 200 diabetic patients (100\%), 83 (41.5\%) patients were females, and 117 (58.5\%) patients were males. In this study, male patients had the highest frequency. There were more males than females in the study.

\section{Age distribution}

Age-wise distribution of patients was enrolled in the study. Out of 200 (100) diabetic patients, 18 (9\%) of the patient were within the age group of $20-39$ years, $78(39 \%)$ of the patients were within the age range of 40-59, the group with the highest frequency was aged from 60 to 79 with $93(46.5 \%)$ patients while the age group of $80-99$ had the lowest frequency of 11 (5.5\%) of patients.

\section{Diabetes type distribution}

Patients enrolled were either type 1 diabetic patient or type 2 diabetic patients. The patient sample had $14(7 \%)$ type 1 diabetic patients out of which two patients (14.3\%) were females and 12 (85.7\%) were males. A total of 186 (93\%) patients had type 2 diabetes. Eighty-one (43.5\%) were females and 105 (56.5\%) were males.

\section{Comorbid conditions of the patients}

The comorbid conditions that were observed in the patients with diabetes mellitus enrolled were collected in the patient profile form that was used in data collection [Table 3].

Table 3: Comorbid conditions of patients

\begin{tabular}{lll}
\hline Comorbid conditions & Frequency (n) & Percentage \\
\hline SHTN & 19 & 9.5 \\
CAD & 8 & 4 \\
CKD & 13 & 6.5 \\
DFU & 35 & 17.5 \\
CKD/CAD & 9 & 4.5 \\
NIL & 18 & 9 \\
SHTN, HYPOTHYROID/CKD & 13 & 6.5 \\
SHTN/CAD/CKD & 21 & 10.5 \\
SHTN/CAD/CVA/MI & 16 & 8 \\
SHTN/CAD/CKD/CVA & 15 & 7.5 \\
CAD/CKD/Retino/Seizure & 20 & 10 \\
SHTN/CKD/Retino/NEUR/DLP & 5 & 2.5 \\
HIV/NEURO,CKD/CVA & 1 & 0.5 \\
LEPROSY/CAD/DFU & 1 & 0.5 \\
SHTN/CKD,CAD/CVA/DLP & 4 & 2 \\
SHTN/Neuro/DLP/CKD/PVD/ & 2 & 1 \\
DVT & & \\
Total & 200 & 100.0 \\
\hline
\end{tabular}

CAD: Coronary artery disease, CKD: Chronic kidney disease, DFU: Diabetic foot ulcer, CVA: Cerebrovascular accident, DLP: Dyslipidemia, PVD: Periphera vascular disease, DVT: Deep vein thrombosis, MI: Myocardial infarction, HIV: Human immunodeficiency virus, SHTN: Systolic hypertension 
Table 4: Descriptive statistics

\begin{tabular}{|c|c|c|c|}
\hline Characteristics & T1DM n= 14 & T2DM n= 186 & All patients $n=200$ \\
\hline Age (mean \pm SD) & $52.8 \pm 20.1$ & $59.9 \pm 19.6$ & $58.6 \pm 19.8$ \\
\hline$<55$ years $(\%)$ & $8(57.1)$ & $88(47.3)$ & $96(48)$ \\
\hline $65+$ years $(\%)$ & $6(48.9)$ & $98(52.7)$ & $104(52)$ \\
\hline Male $(\%)$ & $12(85.7)$ & $105(56.5)$ & $117(58.5)$ \\
\hline Female (\%) & $2(14.3)$ & $81(43.5)$ & $83(41.5)$ \\
\hline Smoking (\%) & $3(21.4)$ & $19(10.2)$ & $22(11)$ \\
\hline Alcohol (\%) & $4(28.6)$ & $32(17.2)$ & $36(18)$ \\
\hline Mixed & $11(78.6)$ & $179(96.2)$ & $190(95)$ \\
\hline Veg & $3(21.4)$ & $7(3.8)$ & $10(5)$ \\
\hline Blood pressure $>140 / 90 \mathrm{mmHg}$ & $5(35.7)$ & $90(48.4)$ & $95(47.5)$ \\
\hline $\mathrm{HbA} 1 \mathrm{c}<6.0 \%$ & $8(57.1)$ & $119(64)$ & $127(63.5)$ \\
\hline $\mathrm{cAG}>140 \mathrm{mg} / \mathrm{dl}$ & $5(35.7)$ & $109(58.6)$ & $117(58.5)$ \\
\hline $\mathrm{RBS}>140 \mathrm{mg} / \mathrm{dl}$ & $11(78.6)$ & $136(73.1)$ & $147(73.5)$ \\
\hline Tchol $>200 \mathrm{md} / \mathrm{dl}$ & $3(21.4)$ & $34(18.3)$ & $37(18.5)$ \\
\hline $\mathrm{HDL}<40 \mathrm{mg} / \mathrm{dl}$ & $7(50)$ & $24(12.9)$ & $31(15.5)$ \\
\hline \multicolumn{4}{|l|}{ Prescribed therapies } \\
\hline Monotherapy & $13(93)$ & $51(27.4)$ & $64(32)$ \\
\hline Double therapy & $1(7.1)$ & $62(33.3)$ & $63(31.5)$ \\
\hline $3+$ drugs & -- & $73(39.2)$ & $73(36.5)$ \\
\hline \multicolumn{4}{|l|}{ Co-morbidity } \\
\hline No co-morbidity (\%) & $6(42.9)$ & $12(6.5)$ & $18(9)$ \\
\hline 1 comorbidity (\%) and $2+$ comorbidities (\%) & $4(28.6)$ & $71(38.2)$ & $75(37.5)$ \\
\hline \multicolumn{4}{|l|}{ Length of stay days } \\
\hline Median (IQR) & $7(3-22)$ & $9(4.5-15)$ & $7(3-12)$ \\
\hline \multicolumn{4}{|l|}{ Hospitalization costs (USD) } \\
\hline Average cost per admission (95\%C1) & $177.5(98-257)$ & $134.5(82-187)$ & $130(85-75)$ \\
\hline Minimum-Maximum & $(45-400)$ & $34-467$ & $248.5(30-467)$ \\
\hline Median cost per admission (IQR) & $125(40-210)$ & $251.5(113-390)$ & $252.5(105-400)$ \\
\hline Total patients $<65$ years cost & 590 & 4,700 & 8,700 \\
\hline Total social security cost & 904 & 2,300 & 3,600 \\
\hline \multicolumn{4}{|l|}{ Payment method } \\
\hline Out of pocket cash & $12(85.7)$ & $127(68.3)$ & $139(69.5)$ \\
\hline
\end{tabular}

Cost from patient perspective, IQR: Interquartile range, SD: Standard deviation, cost in USD United State dollars \$1: ₹60, social security

Table 5: Estimated mean hospitalization costs for diabetic patients

\begin{tabular}{|c|c|c|}
\hline $\begin{array}{l}\text { Patient } \\
\text { characteristics }\end{array}$ & $\begin{array}{l}\text { Discharged Mean } \\
\text { cost }(95 \% \mathrm{C} 1) \text { n }(\% \\
\text { discharge })\end{array}$ & $\begin{array}{l}\text { Mean cost }(95 \% \mathrm{C} 1) \\
\text { n (\% discharged) }\end{array}$ \\
\hline \multicolumn{3}{|l|}{ Women } \\
\hline$<65$ years of age & $467(117,828) 18(69.2)$ & $308(101,691) 8(30.8)$ \\
\hline$>65$ years of age & $137(197,349)(96)$ & $424(202,505)(4)$ \\
\hline \multicolumn{3}{|l|}{ Men } \\
\hline$<65$ years of age & $443(116,866) 99$ & $386(289,681) 0.99$ \\
\hline$>65$ years of age & $120(110,367)$ & $286(184,440)$ \\
\hline \multicolumn{3}{|l|}{ Procedures } \\
\hline No procedure & $114(99,380) 98$ & $68(58,113) 2$ \\
\hline Hemodialysis & $347(290,650) 95$ & $479(401,730) 5$ \\
\hline Physiotherapy & $56(40,125) 98$ & $73(47,146) 2$ \\
\hline Amputation & $130(103,238) 99$ & $537(283,996) 1$ \\
\hline Surgery & $185(375,512) 86$ & $106(235,345) 14$ \\
\hline $\begin{array}{l}\text { Blood } \\
\text { transfusion }\end{array}$ & $116(100,256)$ & $112(245,356)$ \\
\hline Wound care & $288(204,414)$ & $158(103,315)$ \\
\hline
\end{tabular}

Forward stepwise regression analysis of variables predictive of hospitalization cost [Tables 6 and 7]

Stepwise regression analysis of variables such as Prescribed therapies, procedures and co-morbidities of hospitalization cost are discussed under [Table 6] and also the Estimated cost for individual drug for patients on drugs per annum is discussed in [Table 7].
Table 6: Regression analysis $n=200$

\begin{tabular}{|c|c|c|c|}
\hline Variables & Coefficient & $\begin{array}{l}\text { Std } \\
\text { error }\end{array}$ & p-value \\
\hline \multicolumn{4}{|l|}{ (Intercept) Age } \\
\hline Reference: $<65$ years of age & 5.59 & 0.27 & $<0.001$ \\
\hline $65+$ years & -0.29 & 0.08 & \\
\hline \multicolumn{4}{|l|}{ Prescribed therapies } \\
\hline $3+$ therapies & 1.66 & 0.23 & $<0.001$ \\
\hline 2 therapies & 1.24 & 0.25 & $<0.001$ \\
\hline \multicolumn{4}{|l|}{ Procedures } \\
\hline Wound care & 0.78 & 0.20 & $<0.001$ \\
\hline Amputation & 1.16 & 0.35 & $<0.001$ \\
\hline Dialysis & 0.65 & 0.18 & $<0.001$ \\
\hline Physiotherapy & 0.22 & 0.10 & 0.026 \\
\hline \multicolumn{4}{|l|}{ Comorbidity } \\
\hline $2+$ co-morbidities & 0.32 & 0.14 & 0.026 \\
\hline Systolic blood pressure & -0.002 & 0.001 & 0.031 \\
\hline
\end{tabular}

Drug utilization trend

In the patient sample, anti-diabetic drugs were the most frequently used. Oral and parenteral dosage forms were used which included insulin administration subcutaneously and intravenously together with intravenous fluids to correct cases of hyperglycemia and hypoglycemia. Due to the presence of comorbid conditions, the cost burden of drugs increased, and the percentage distribution is shown in the diagram below [Table 8]. 
Table 7: Estimated cost for individual drug for patients on drugs per annum

\begin{tabular}{|c|c|c|c|c|}
\hline Drug & Total cost & $\%$ drug cost & Number of patients & $\%$ patients \\
\hline Metformin & $51,810(863.5)$ & 10.7 & 147 & 53 \\
\hline Glimepiride & $47,227(787.11)$ & 14.3 & 67 & 33.5 \\
\hline Glipizide & $30,408(506.8)$ & 3.3 & 33 & 16.5 \\
\hline Saxagliptin & $11,340(189)$ & 1.2 & 25 & 12.5 \\
\hline Sitagliptin & $9474(157.90)$ & 1 & 58 & 29 \\
\hline Vildagliptin & $38,451(640.85)$ & 4.2 & 43 & 21.5 \\
\hline Voglibose & $2,034(33.90)$ & 0.2 & 13 & 6.5 \\
\hline Metformin+sitagliptin & $58,710(978.50)$ & 6.4 & 78 & 39 \\
\hline Metformin+vidagliptin & $20,588(343.14)$ & 2.3 & 68 & 34 \\
\hline Metformin+voglibose & $10,961.4(182.69)$ & 1.2 & 21 & 10.5 \\
\hline Other diabetic drugs & $49,680(828.0)$ & 5.4 & & \\
\hline Insulin & $170,588.4(2843.14)$ & 18.7 & 43 & 21.5 \\
\hline Other non-diabetic agent & $285,653.4(4760.89)$ & 31.3 & 171 & 85.5 \\
\hline Total & $914,116.8(15235.28)$ & 100 & & \\
\hline
\end{tabular}

Table 8: Cost of illness for patients

\begin{tabular}{lll}
\hline $\begin{array}{l}\text { Cost } \\
\text { components }\end{array}$ & $\begin{array}{l}\text { Total cost of drug } \\
\text { INR, USD }\end{array}$ & $\begin{array}{l}\text { \% total } \\
\text { illness cost }\end{array}$ \\
\hline Drugs & $914,116.8(15,235.28)$ & 57.7 \\
Transport & $26,610(443.5)$ & 1.7 \\
Diagnostic tests & $72,066(1,201.1)$ & 4.5 \\
Procedures & $438,051(7,300.85)$ & 27.7 \\
Personnel cost & $133,267.2(2,221.12)$ & 8.4 \\
Total & $1,584,111(26,401.85)$ & 100 \\
\hline
\end{tabular}

Table 9: Characteristics of patients' diabetic complications

\begin{tabular}{ll}
\hline Complications and risk factors & Diabetic patients $\mathbf{n = 2 0 0}$ \\
\hline Diabetes duration (years), mean (SD) & $22.1(14.2)$ \\
Body mass index, $\mathrm{kg} / \mathrm{m}^{2}$, mean (SD) & $25.8(4.8)$ \\
Smoking & $22(11)$ \\
Alcohol & $36(18)$ \\
Complications & \\
Impaired vision & $28(14)$ \\
Myocardial infarction & $33(16.5)$ \\
Angina & $19(9.5)$ \\
Nephropathy & $49(24.5)$ \\
Foot ulcer & $41(20.5)$ \\
Amputation & $37(18.5)$ \\
Stroke & $19(9.5)$ \\
Neuropathy & $17(8.5)$ \\
Other & $53(26.5)$ \\
None & $19(9.5)$ \\
\hline
\end{tabular}

Table 10: Distribution of levels of perceived problem in each of the dimensions of EQ-5D descriptive system in diabetic patients

\begin{tabular}{llll}
\hline $\begin{array}{l}\text { levels of perceived } \\
\text { problem }\end{array}$ & \multicolumn{4}{l}{$\begin{array}{l}\text { Type 1 and type 2 patients }(\mathbf{n}=\mathbf{2 0 0}), \\
\text { Levels of perceived problem } \mathbf{n}(\%)\end{array}$} \\
\hline Dimension & $1^{*}$ & $2^{*}$ & $3^{*}$ \\
Mobility & $80(40)$ & $78(39)$ & $50(25)$ \\
Self-care & $110(55)$ & $60(30)$ & $30(15)$ \\
Usual activities & $97(48.5)$ & $76(38)$ & $27(13.5)$ \\
Pain/discomfort & $40(20)$ & $87(43.5)$ & $73(36.5)$ \\
Anxiety/depression & $57(28.5)$ & $68(34)$ & $75(37.5)$ \\
\hline
\end{tabular}

*Level 1: No problem, 2: Moderate problem, 3: Severe problem

\section{HRQoL}

HRQoL is the measure of patient value in terms of the impact of disease and its treatment on physical functioning and psychological well-being. The data in this section show the diabetes complications and their influence on the HRQoL. This was analyzed using the linear regression model and the binomial logistic regression of responses to the EQ-5D descriptive system [Tables 9 and 10].

Out of 200 patients, $25 \%$ had severe problems with mobility. Most of these patients had a history of amputation once or twice, either toe, or below-knee amputation. About 39\% of the patients had reported having moderate problems in mobility while $40 \%$ of the patients had no problems at all. In self-care, $15 \%$ of the patients had severe problems and had to rely on family members and caregivers, $30 \%$ had some level of difficulty, and $55 \%$ of the patients had no problem at all. About $13.5 \%$ of patients had problems with usual activities, $46.5 \%$, and $36.5 \%$ had moderate to severe pain and discomfort, respectively. Furthermore, $34 \%$ and $37.5 \%$ of the patients suffered from moderate to severe depression [Tables 11-13].

\section{DISCUSSION}

Diabetes is a metabolic disorder characterized by high cost since its a chronic condition treated for a lifetime, complications, and high resource utilization. Diabetes is an awfully expensive disease for the patient and the state health-care system. The patients' sociodemographic characteristics, resource utilization, that is, medical comorbidity, medical complications, and outcome (discharged or decrease), prescribed treatment, and procedures increase the total hospital cost.

Out of 200 diabetic patients (100\%), 83 (41.5) patients were females, and 117 (58.5\%) patients were males. In this study, male patients had the highest frequency. There were more males than females in the study. Eighteen (9\%) of the patients were within the age group of $20-39$ years, $78(39 \%)$ of the patients were within the age range of $40-59$, the group with the highest frequency was aged from 60 to 79 with 93 (46.5) patients while the age group of 80-99 had the lowest frequency of 11 (5.5\%). Patients enrolled were either type 1 diabetic patient or type 2 diabetic patients. The patient sample had 14 (7\%) type 1 diabetic patients out of which $2(14.3 \%)$ were females and $12(85.7 \%)$ were males. A total of $186(93 \%)$ patients had type 2 diabetes out of which 81 (43.5\%) were females and 105 (56.5) were males.

The comorbid conditions of the 200 patients of the study were: About $58.5 \%$ of the patients had hypertension and hence anti-hypertensive drugs were prescribed and some of them were of beneficence in the kidney by reducing volume overload for patients who have both hypertension and chronic kidney disease (CKD). In diabetic patients who had CKD, mostly insulin was prescribed. Any drug that has nephrotoxic effects is contraindicated as they exacerbate sugar levels. Cardiovascular disorders had the highest frequency as a comorbid condition and they further increased the cost burden to the patient. Some patients were placed on hemodialysis and others 
Table 11: Linear multivariate regression of EQ-5D index

\begin{tabular}{|c|c|c|c|c|}
\hline $\mathbf{n}$ & $\begin{array}{l}\text { Type 1, 14, Coefficient } \\
\text { (95\% C1) }\end{array}$ & $P>|t|$ & $\begin{array}{l}\text { Type } 2,186, \text { Coefficient } \\
(95 \% \text { C1) }\end{array}$ & $\mathbf{P}>|\mathbf{t}|$ \\
\hline Constant & $1.092(0.921$ to 1.263$)$ & $<0.001$ & $0.990(0.787$ to 1.193$)$ & $<0.001$ \\
\hline Sex $($ male $=0$, female $=1)$ & $0.041(-0.023$ to 0.105$)$ & 0.210 & $0.024(-0.016$ to 0.064$)$ & 0.240 \\
\hline Age (in 10 years) & $-0.003(-0.022$ to 0.016$)$ & 0.749 & $0.0004(-0.017$ to 0.017$)$ & 0.967 \\
\hline Impaired vision $($ no $=0$, yes $=1)$ & $-0.063(-0.169-0.044)$ & 0.245 & $-0.012(0.074$ to 0.051$)$ & 0.711 \\
\hline Ischemic heart disease (no $=0$, yes $=1$ ) & $-0.181(-0.331$ to -0.031$)$ & 0.019 & $-0.037(-0.103$ to 0.030$)$ & 0.276 \\
\hline Proteinuria $($ no $=0$, yes $=1)$ & $0.089(-0.036$ to 0.215$)$ & 0.161 & $0.043(-0.019$ to 0.106$)$ & 0.174 \\
\hline Stroke $($ no $=0$, yes $=1)$ & $-0.291(-0.475$ to -0.108$)$ & 0.002 & $-0.135(-0.247$ to -0.023$)$ & 0.018 \\
\hline Neuropathy (no=0, yes $=1$ ) & $-0.358(-0.535$ to -0.180$)$ & $<0.001$ & $-0.187(-0.316$ to -0.057$)$ & 0.005 \\
\hline Body mass index $(\mathrm{kg} / \mathrm{m} 2)$ & $-0.004(-0.008$ to 0.001$)$ & 0.123 & $-0.002(-0.007$ to 0.002$)$ & 0.307 \\
\hline Disability pension $($ no $=0$, yes $=1)$ & $-0.111(-0.191$ to -0.030$)$ & 0.008 & $-0.100(-0.153$ to -0.046$)$ & $<0.001$ \\
\hline Number of hospital admissions during the past 6 months & $0.003(-0.042$ to 0.049$)$ & 0.880 & $-0.028(-0.076$ to 0.020$)$ & 0.255 \\
\hline Receives help from others (no=0, yes $=1$ ) & $-0.090(-0.217$ to 0.037$)$ & 0.166 & $-0.123(-0.185$ to -0.060$)$ & $<0.001$ \\
\hline Hypoglycemia index* & $-0.023(-0.071$ to 0.025$)$ & 0.337 & $-0.004(-0.039$ to 0.032$)$ & 0.839 \\
\hline Fear of hypoglycemia** $($ small $=0$, large $=1)$ & $-0.021(-0.071$ to 0.025$)$ & 0.432 & $-0.078(-0.129$ to -0.028$)$ & 0.003 \\
\hline Limitations socially** (small $=0$, large $=1)$ & $-0.107(-0.188$ to -0.026$)$ & 0.010 & $-0.002(-0.049$ to 0.046$)$ & 0.944 \\
\hline
\end{tabular}

*Self-reported episodes of hypoglycemia, with four levels of severity (level 1: Hypoglycemia cured with the intake of, for example, fluid containing sugar; no help required, level 2: Hypoglycemia cured with the intake of, for example, fluid containing sugar; help from others required, level 3: Hypoglycemia with help from doctor required (no hospital admission), level 4: Hypoglycemia resulting in hospital admission), then added with severity weights (level $1 * 1$, level $2 * 2$, level $3 * 3$, level $4 * 4$ ), and finally divided into three groups: $0,1-11$ and 12 to max. Self-reported on a scale from 1 to 5 (1=not at all, $5=$ very much), recorded to two levels ( $>$ and $<2.5$ due to imputed values having values with decimals)

Table 12: Multivariate logistics regression of responses to the ED-5D items in diabetic patients: Odds ratio 95\% CI, EQ 5D distribution

\begin{tabular}{|c|c|c|c|c|c|}
\hline Items in diabetic patients & Mobility & Self-care & Usual activities & $\begin{array}{l}\text { Pain/ } \\
\text { discomfort }\end{array}$ & $\begin{array}{l}\text { Anxiety/ } \\
\text { Depression }\end{array}$ \\
\hline Sex: Male $=0$ & $0.48(0.38-1.21)$ & $0.59(0.23-1.54)$ & $* 0.47(0.25-0.88)$ & $0.82(0.53-1.27)$ & $0.91(0.54-1.52)$ \\
\hline Age in 10 years & *1.36 (1.03-1.80) & $0.83(0.55-1.25)$ & $1.34(1.00-1.80)$ & $1.03(0.83-1.24)$ & *0.78 (0.62-0.99) \\
\hline Impaired vision: Normal $=0$ & $2.96(1.44-6.10)$ & $2.99(0.77-6.75)$ & $0.89(0.39-2.04)$ & -- & $1.46(0.71-3.01)$ \\
\hline \multicolumn{6}{|l|}{ Reduced $=1$} \\
\hline $\begin{array}{l}\text { Ischemic heart disease: } \\
\text { No=0,Yes }=1\end{array}$ & $1.97(0.91-4.25)$ & $1.77(0.54-5.86)$ & $1.14(0.48-9.39)$ & $2.51(1.27-4.97)$ & $1.15(0.56-2.50)$ \\
\hline Proteinuria & -- & -- & -- & -- & $0.42(0.14-1.29)$ \\
\hline \multicolumn{6}{|l|}{$\mathrm{No}=0, \mathrm{Yes}=1$} \\
\hline Foot ulcer & $0.32(0.07-1.39)$ & $0.73(0.11-4.67)$ & $2.11(0.48-9.39)$ & $2.18(0.54-8.79)$ & $* 7.00(1.53-31.97)$ \\
\hline Stroke & $3.50(1.13-10.82)$ & -- & -- & -- & -- \\
\hline \multicolumn{6}{|l|}{$\mathrm{No}=0, \mathrm{Yes}=1$} \\
\hline Neuropathy & $12.07(3.30-44.12)$ & $2.74(0.57-8.95)$ & $3.08(0.84-11.26)$ & Predicts & $1.29(0.40-4.16)$ \\
\hline $\mathrm{No}=0, \mathrm{Yes}=1$ & & & & correctly\# & \\
\hline Hypoglycemic index & -- & -- & -- & $1.68(1.13-2.49)$ & $1.08(0.7-1.68)$ \\
\hline Fear of hypoglycemia & -- & -- & -- & -- & $* * * 5.76(3.36-9.87)$ \\
\hline \multicolumn{6}{|l|}{ Small $=0$, Large $=1$} \\
\hline $\begin{array}{l}\text { Limitations at work; } \\
\text { small=0, Large }=1\end{array}$ & -- & -- & $* * * 6.95(3.95-13.56)$ & -- & -- \\
\hline Limitations socially: & -- & -- & $1.33(0.67-2.62)$ & --- & -- \\
\hline Small $=0$, Large $=1$ & & & & & \\
\hline $\begin{array}{l}\text { Nephropathy dialysis: } \mathrm{No}=0 \text {, } \\
\text { Yes }=1\end{array}$ & $3.96(2.05-8.09)$ & $2.11(0.56-7.11)$ & $0.73(0.12-4.56)$ & $1.23(2.31-9.87)$ & $6.71(1.97-9.67)$ \\
\hline Log likelihood & -136.08 & -66.13 & -136.85 & 232.10 & -187.32 \\
\hline
\end{tabular}

${ }^{*} \mathrm{p}<0.05,{ }^{* *} \mathrm{p}<0.01,{ }^{* * *} \mathrm{p}<0.001,{ }^{*}$ All patients reporting neuropathy also reports having problems in PAIN/DISCOMFORT dimensions of the EQ-5D. Cells with dotted line indicate that the variable was not included in the model. \#Self-reported episodes of hypoglycemia, with four levels of severity (level $1=$ =hypoglycemia cured with the intake of, for example, fluid containing sugar; no help from others required, level 2=hypoglycemia cured with the intake of, for example, fluids containing sugar; help from others required, level 3=hypoglycemia with help from the doctor required (no hospital admission), level 4=hypoglycemia resulting in hospital admission); added with severity weights (level $1 * 1$, level $2 * 2$, level $3 * 3$, level $4 * 4$ ) and finally divided into three groups: $0,1-11$ and 12 to max. \#\# Self-reported on a scale from 1 to 5 (1=not at all, $5=$ very much), recorded to two levels ( $>$ and $<$ than 2.5 due to imputed values having values with decimals)

on conservative treatment. One case was because of chronic use of NSAIDs. Regular screening of diabetic patients at risk of nephropathy might and the routine monitoring of renal functions will improve the risk of the patient developing more complications as the disease progresses.
The high cost of therapy results in poor patient compliance by some patients thus, leading to other complications in addition to renal problems which affects the quality of life adversely. Diabetic foot ulcer, if not treated properly will result in amputation, toe or belowknee amputation, and also the risk of developing another case of 
Table 13: Mean EQ-5D index utility values with and without diabetes-related complications

\begin{tabular}{|c|c|c|c|c|c|c|}
\hline \multirow{2}{*}{$\begin{array}{l}\text { Number of } \\
\text { complications }\end{array}$} & \multicolumn{3}{|c|}{ Type 1 diabetes } & \multicolumn{3}{|c|}{ Type 2 diabetes } \\
\hline & $\begin{array}{l}\text { EQ-5D } \\
\text { index }\end{array}$ & $95 \% \mathrm{CI}$ & $\mathbf{n}$ & $\begin{array}{l}\text { EQ-5D } \\
\text { index }\end{array}$ & $95 \% \mathrm{CI}$ & $\mathbf{n}$ \\
\hline 0 & 0.90 & $0.88-093$ & 6 & 0.85 & $0.82-0.8$ & 12 \\
\hline 1 & 0.76 & $0.66-0.86$ & 4 & 0.80 & $0.75-0.85$ & 71 \\
\hline$\geq 2$ & 0.55 & $0.37-0.73$ & 4 & 0.64 & $0.56-0.71$ & 103 \\
\hline $\begin{array}{l}\text { Any } \\
\text { complications }\end{array}$ & 0.68 & $0.59-0.77$ & 8 & 0.73 & $0.69-0.78$ & 174 \\
\hline All patients & 0.83 & $0.79-0.87$ & 14 & 0.81 & $0.79-0.83$ & 186 \\
\hline
\end{tabular}

ulcer or delayed wound healing which results in increased length of stay. Neuropathy consisted of $8.5 \%$ of cases that were recorded while retinopathy cases were $14 \%$ of the population sample.

Measures such as the diabetic compatible lifestyle improve compliance to the need of medication to be taken into consideration to prevent the complications associated with Diabetes, thereby, subsequently improving the quality of life. Other modalities entail possible home visits by the social workers or community pharmacy workers to improve patient compliance even though the procedure may result in an increased cost burden. It should be noted that the cost beneficence of such programs must also be considered.

The total cost of illness as stipulated in this study results implied that the estimated total cost of illness was (INR 5,584,111), USD 26401.85 for all the 200 patients. The average cost per year per patient is INR $(15,180)$ USD $\$ 253$, transport accounted for (INR 26,610) USD \$443, diagnostic tests (INR 72,066) USD $\$ 1,201$, procedures (INR 438,051) USD $\$ 7300.85$, and personnel cost (INR 133,267.2) USD \$2,221.2. This considers the direct cost of therapy that is the procurement cost of drugs, transport cost, diagnostic test cost, personnel cost of health professionals in the event of hospitalization or routine hospital visits, and check-ups. The average cost per year represents $41.1 \%$ of the yearly per capita income. The indirect cost of diabetes disease management was excluded from the study, however spending about $40.6 \%$ of the annual per capita income on disease management is a great economic burden. The total cost of drug procurement was (INR 914,116.8) USD $15,235.28$ of the total cost of illness. This is a ridiculously huge amount and therefore any measures that can be taken to reduce the financial load and promote more rational drug selection such as economic evaluation of therapy, regular updates of the formulary, and evidencebased standard treatment guidelines, will be most valuable in ensuring effective resource utilization.

The effects of blood glucose controlling diabetes treatment are measured in terms of glycosylated hemoglobin that reflects mean blood glucose levels during the recent 2-3 months. Having uncontrolled blood glucose levels over time leads to diverse consequences which may be short-term complications defined as symptoms directly caused by hyperglycemic or hypoglycemic episodes, long-term microvascular or macrovascular complications, and loss of life years.

Long-term complications lead to decreased quality of life. The cost for reduction of $\mathrm{HbA} 1 \mathrm{c}$ values by $1 \%$ ranges from $($ INR 6,900$) \$ 115$ $\$ 164(9,840)$. This value is cost-effective when compared to overall cost savings that have been estimated to result from a $1 \% \mathrm{HbA} 1 \mathrm{c}$ reduction which amounts to $\$ 1,200$ (INR 72,000).

Out of 200 patients, $25 \%$ had severe problems with mobility. Most of these patients had a history of amputation once or twice, toe or below-knee amputation. About $59 \%$ of the patients had reported having moderate problems in mobility while $40 \%$ of the patients had no problem at all. In self-care $15 \%$ of the patients had severe problems and had to rely on the family members and caregivers, $30 \%$ had some level of difficulty, $55 \%$ of the patients had no problem at all. About $13.5 \%$ of patients had problems with usual activities, $46.5 \%$, and $36.5 \%$ had moderate to severe pain and discomfort, respectively. Furthermore, $34 \%$ and $37.5 \%$ of the patients suffered from moderate to severe depression. The mean EQ-5D index score was $0.83(\mathrm{SD}=0.24)$ in type 1 diabetes and $0.81(S D=0.22)$ in type $2(p=0.32)$. For patients without reported complications, the mean EQ-5D index scores were 0.90 in type 1 diabetes and 0.85 in type 2 diabetes. The presence of one complication decreased values to 0.76 and 0.80 . With two or more diabetes-related complications, values were 0.55 and 0.64 . HRQoL was largely dependent on the presence of major diabetes-related complications. Complications with the most severe impact were amputation, neuropathy, nephropathy, stroke, ischemic heart disease, and myocardial infarction.

In the regression analysis of diabetes on EQ-5D dimension responses, age, impaired vision, fear of hyperglycemia, ischemic heart disease, foot ulcer, neuropathy, body mass index, hospital admissions, and receiving help from others were statistically significant determinants for mobility problems and anxiety/depression.

\section{CONCLUSION}

The research study provides a general estimate of the cost of illness of diabetes and the impact of diabetic complications on the HRQoL. Diabetes is characterized by a very high-cost burden. Education on the prevention and management of diabetes must be prioritized. It must be provided to diabetic patients and the society at large. Therefore, it is suggested that Health-care providers and policy-makers must put more attention to the factors that result in increased hospital care. Furthermore, the introduction of intensive disease management interventions to diabetic patients to delay the progression of complications or comorbidities will result in a reduction of health care expenditure and improved quality of life and the life years, thereby decreasing the premature mortality rate caused by diabetes. A lower financial burden on patients would greatly increase the treatment compliance, complications, and comorbidity progression. This will result in a reduction of diabetes' economic burden on patients, society, and the health-care system. This study was limited due to time constraints. Further multicenter studies can be carried out in a larger population in different geographical regions in India or it can be done at a national scale.

\section{ACKNOWLEDGMENT}

The authors would like to thank hospital authorities, SRM Medical College Hospital and Research Centre, for their constant guidance and support throughout our project.

\section{REFERENCES}

1. World Health Organization. Health Economics, Drug, and Health Sector Reform. WHO Task Force on Health Economics. Geneva: World Health Organization; 2017

2. Cano SB, Crane VS. Conceptual Model for Assuring Cost Effectiveness in Hospital Pharmacy Practice. Brentford, United Kingdom: Glaxo; 1989.

3. Wagner EH, Sandhu N, Newton KM, Mc Culloh effect of improved glycaemic control on health care cost and utilization. JAMA 2014;285:182-9

4. Cho E, Rimm EB, Stampfer MJ. The impact of diabetes mellitus and prior myocardial infarction on mortality from all causes and from coronary heart disease in men. J Am Coll Cardiol 2012;40:954-60

5. Dawson KG, Gomes D, Gerstein H, Blanchard JF, Kahler KH. The economic cost of diabetes in Canada, 1998. Diabetes Care 2002;25:1303-7. 